\title{
Desain Pembelajaran Kerucut Berkonteks Tradisi Megono Gunungan
}

\author{
Farida Nursyahidah $^{1 *}$, Bagus Ardi Saputro ${ }^{2}$, Irkham Ulil Albab ${ }^{3}$ \\ ${ }^{1,3}$ Program Studi Pendidikan Matematika, Universitas PGRI Semarang \\ ${ }^{2}$ Program Studi PGSD, Universitas PGRI Semarang \\ *faridanursyahidah@upgris.ac.id
}

\begin{abstract}
Abstrak
Geometri merupakan salah satu materi yang penting bagi siswa. Namun, materi geometri khusunya bangun ruang sisi lengkung kerucut masih menjadi materi yang sulit bagi siswa. Sehingga diperlukan media dan konteks yang tepat dalam pembelajaran matematika pada materi kerucut. Oleh karena itu, penelitian ini bertujuan untuk mengembangkan lintasan belajar dengan menggunakan tradisi Megono Gunungan sebagai konteks dalam proses pembelajaran menggunakan pendekatan Pendidikan Matematika Realistik Indonesia (PMRI). Metode penelitian yang digunakan adalah Design Research yang terdiri dari tiga tahapan, yaitu preliminary design, design experiment, dan retrospective analysis. Hasil dari penelitian ini merupakan desain lintasan belajar pada materi kerucut menggunakan tradisi Megono Gunungan. Lintasan belajar ini terdiri dari 4 aktivitas, yaitu mengamati video interaktif tradisi Megono Gunungan untuk menemukan unsur-unsur kerucut, menemukan konsep luas permukaan kerucut menggunakan kertas origami, menemukan konsep volume kerucut dengan bijibiji ajaib, dan menyelesaikan masalah kontekstual berkaitan dengan kerucut. Hasil penelitian ini menunjukkan bahwa penggunaan konteks Megono Gunungan dapat menstimulasi pemahaman konsep siswa terhadap materi kerucut. Selanjutnya, hasil penelitian ini diharapkan dapat dijadikan sebagai inspirasi eksplorasi kearifan lokal lainnya yang dapat dijadikan sebagai konteks dalam pembelajaran matematika.
\end{abstract}

Kata kunci: design research, kerucut, lintasan belajar, tradisi Megono Gunungan,

PMRI

\begin{abstract}
Geometry is an essential subject for students. However, geometry, especially the cone, remains a challenging material for students. Besides, we need the proper media and context for learning mathematics on cone material. This research aims to develop a learning trajectory that utilizes the Megono Gunungan tradition as a context in the learning process using the Indonesian Realistic Mathematics Education (PMRI) approach. The research method used is Design Research, which consists of three phases of the study: preliminary design, experimental design, and retrospective study. This study's outcome is designing a learning trajectory on cone material using the Megono Gunungan tradition. This learning trajectory comprises four activities, including observing the interactive video of the Megono Gunungan tradition to discover cone elements, finding the concept surface area of a cone using origami paper, and grasping the cone concept volume with magic seeds, and solving contextual problems related to the cone. Studies have shown that using the Megono Gunungan context could help students improve their understanding of the cone concept. Furthermore, this study hoped could be an inspiration for exploring another local wisdom that can be a context in learning mathematics.
\end{abstract}

Keywords: cone, design research, learning trajectory, Megono Gunungan tradition, PMRI 


\section{Pendahuluan}

Matematika dalam kurikulum sekolah memuat beberapa topik materi, dan geometri merupakan salah satu topik terpenting (Clemesnts \& Sarama, 2011; Alex \& Mammen, 2016; Doğruer, 2018). Pembelajaran geometri di kelas memuat materi hubungan antara bentuk geometri, struktur, teorema dan rumus saat pembelajaran geometri di kelas (Keşan \& Çalışkan, 2013). Dalam kurikulum pendidikan Indonesia, geometri juga merupakan salah satu materi yang dipelajari dari sekolah dasar hingga sekolah menengah (Kemendikbud, 2016). Oleh karena itu, penting bagi siswa untuk dapat menguasai materi geometri. Hal tersebut sesuai dengan pendapat Couto dan Vale (2014) yang menyatakan bahwa perkembangan pemikiran geometris merupakan alat bantu penting untuk menyelesaikan masalah dalam kehidupan seharihari siswa.

Namun, beberapa penelitian menyebutkan bahwa tingkat pemikiran geometris siswa tingkat pendidikan dasar dan menengah masih berada di bawah tingkat yang diharapkan (Alex \& Mammen, 2012; Serin, 2018). Kesulitan siswa pada materi geometri karena konsep dasar yang harus dikuasai lebih abstrak daripada bidang pembelajaran matematika lainnya (Özdemir, 2017; Adelabu, et al., 2019). Pernyataan tersebut didukung oleh Sinclair dan Bruce (2015) yang mengatakan bahwa siswa tidak memahami keselurahan materi saat pembelajaran geometri karena geometri penuh dengan gambar abstrak yang sulit dipahami oleh siswa. Hal ini disebabkan materi geometri masih menjadi problematis bagi siswa (Bhagat \& Chang, 2015; Yavuz, et al., 2016).

Salah satu materi geometri yang masih dirasa sulit oleh siswa adalah kerucut. Kesulitan siswa pada materi geometri khususnya kerucut adalah siswa belum mampu menentukan unsurunsur kerucut, tidak memahami konsep rumus luas permukaan dan volume kerucut, serta tidak dapat menyelesaikan masalah berkaitan kerucut dengan benar (Arifin, dkk., 2018). Selanjutnya, kesulitan siswa terletak pada pemahaman konsep tentang selimut kerucut dan garis pelukis, serta siswa lebih cenderung menghafal rumus kerucut (Lithner, 2011).

Beberapa faktor yang menyebabkan kesulitan siswa pada materi bangun ruang sisi lengkung adalah penyampaian materi oleh guru yang sulit dimengerti siswa, terbatasnya penggunaan media konkrit oleh guru, dan proses pembelajaran yang kurang bermakna (Novita, dkk., 2018). Guru merupakan salah satu faktor penentu ketercapaian tujuan pembelajaran dalam pendidikan, khususnya pada pembelajaran geometri (Armah, 2018; Javad, \& Reza, 2017). Salah satu faktor yang penting dalam ketercapaian tujuan pembelajaran adalah metode pengajaran yang dilakukan guru di kelas (Najafipour, et al., 2013). 
Sejalan dengan permasalahan di atas, maka penting bagi guru untuk merancang pembelajaran kerucut yang lebih bermakna dengan menggunakan konteks dan pendekatan yang tepat. Salah satu pendekatan dalam pembelajaran matematika yang dapat mendukung pembelajaran menjadi lebih bermakna adalah Pendidikan Matematika Realistik Indonesia (PMRI) (Bustang, et al., 2013; Juwita, dkk., 2015; Putri \& Zulkardi, 2019; Nursyahidah, et al., 2020; Risdiyanti \& Prahmana, 2020). Konteks nyata yang dekat dengan siswa merupakan titik awal pembelajaran PMRI untuk dapat menjadi jembatan antara pengetahuan nyata yang dialami siswa menuju pengetahuan formal matematika siswa (Yanti, dkk., 2016; Putri \& Zulkardi, 2017). Penggunaan konteks dalam pembelajaran matematika dapat membuat konsep matematika menjadi lebih bermakna karena konteks dapat memudahkan siswa untuk memahami bentuk representasi dari konsep matematika yang abstrak (Haris \& Putri, 2011; Prahmana, et al., 2012; Nursyahidah, et al., 2013, 2014, 2018).

Konteks yang diaplikasikan dalam penelitian ini adalah tradisi Megono Gunungan yang merupakan salah satu tradisi budaya nusantara dari Jawa Tengah, khususnya kota Pekalongan. Dalam tradisi tersebut bentuk Megono Gunungan dapat memvisualisasikan bentuk bangun ruang sisi lengkung kerucut. Penggunaan konteks sebagai titik awal pembelajaran kerucut yang dikemas dengan video interaktif diharapkan dapat memudahkan siswa dalam pemahaman konsep materi kerucut. Sebagaimana dalam kajian sebelumnya yaitu dengan menggunakan konteks Megono Gunungan dalam rancangan lintasan pembelajaran dapat membantu memudahkan siswa dalam memahami materi kerucut (Nursyahidah, dkk, 2020).

Berdasarkan latar belakang tersebut, peneliti melaksanakan studi dengan tujuan mengembangkan lintasan pembelajaran untuk membantu menstimulasi pemahaman konsep siswa terhadap materi kerucut melalui konteks Megono Gunungan yang dikemas dalam bentuk video interaktif.

\section{Metode}

Studi ini menggunakan metode penelitian Design Research yang dikembangkan oleh Gravemeijer dan Cobb (2006). Design research merupakan metodologi yang bertujuan untuk meningkatkan pengaruh dan transformasi penelitian pendidikan ke dalam praktik (Anderson \& Shattuck, 2012). Fase dalam Design Research terdiri dari 3 tahap, yaitu: preliminary design, design experiment yang terdiri dari dua fase yaitu pilot experiment dan teaching experiment, dan restrospective analysis (Bakker, 2004; Graveimeijer \& Cobb, 2006, Prahmana, 2017). Namun, penelitian ini terbatas pada tahap pilot experiment dalam design experiment yang 
dilaksanakan pada bulan Januari-Maret 2020. Siswa kelas 3 SMP Negeri 38 Semarang, Jawa Tengah, merupakan subjek dalam studi penelitian ini.

Pada tahap preliminary design, peneliti bersama guru model melakukan analisis materi kerucut sesuai dengan kurikulum di sekolah yang bersangkutan dan penggunaan PMRI sebagai pendekatan pembelajaran. Hasil analisis tersebut disusun untuk merancang serangkaian aktivitas pembelajaran kerucut dalam bentuk Hyphotetical Learning Trajectory (HLT). HLT digunakan secara dinamis, sehingga fleksibel dan dapat direvisi pada tahap design experiment (pilot experiment dan teaching experiment). Selain itu, dalam pilot experiment melibatkan 6 siswa dengan kemampuan heterogen, yaitu berkemampuan tinggi, sedang, dan rendah masingmasing 2 siswa. Pemilihan siswa tersebut berdasarkan hasil belajar materi sebelumnya dan atas pertimbangan dari guru kelas yang sudah memahami kemampuan dan kondisi siswa. Pengumpulan data meliputi observasi, rekaman video kegiatan di kelas dan diskusi kelompok, pengumpulan data siswa, pelaksanaan pre-test dan post-test, dan wawancara siswa. Teknik analisis data dilaksanakan secara kualitatif dan membandingkan hasil observasi selama kegiatan belajar mengajar dengan rancangan HLT yang telah didesain.

\section{Hasil Penelitian}

Hasil yang dididapat dalam studi ini ialah lintasan pembelajaran materi kerucut dengan menggunakan konteks tradisi Megono Gunungan. Lintasan aktivitaas pembelajaran ini terdiri dari empat aktivitas. Aktivitas pertama adalah mengamati video interaktif tradisi Megono Gunungan untuk menemukan unsur-unsur kerucut. Selanjutnya, aktivitas kedua adalah menemukan konsep luas permukaan kerucut menggunakan kertas origami. Kemudian, aktivitas ketiga adalah menemukan konsep volume kerucut dengan biji-biji ajaib. Terakhir, aktivitas keempat adalah menyelesaikan masalah kontekstual berkaitan dengan kerucut. Lintasan aktivitaas pembelajaran kerucut tersebut dapat dilihat pada gambar 1.

Dari serangkaian aktivitas yang telah dirancang, siswa mampu menguasai konsep luas permukaan dan volume kerucut dengan lebih mudah menggunakan konteks tradisi Megono Gunungan dalam bentuk video interaktif yang dapat dilihat dari hasil jawaban siswa pada Lembar Aktivitas Siswa (LAS), tes akhir, dan wawancara. Untuk lebih jelasnya, uraian hasil dari penelitian ini disajikan sebagai berikut.

\section{Aktivitas 1: Mengamati video interaktif tradisi Gunungan Megono}

Sebelum guru memulai materi pembelajaran, guru memberikan materi apersepsi dengan sistem tanya jawab dan meminta beberapa siswa untuk menjelaskan konsep materi yang telah dibahas sebelumnya, yaitu materi luas permukaan dan volume tabung. Siswa sangat antusias 
dalam materi apersepsi ini yang ditunjukan dari keaktifan siswa saat melakukan tanya jawab. Peneliti memberikan LAS 1 yang memuat beberapa pertanyaan kontekstual. Setelah itu, siswa diminta untuk mengamati video interaktif tradisi Megono Gunungan untuk dapat mensketsakan bentuk Megono Gunungan yang merepresentasikan bentuk kerucut, mengidentifikasi, dan menemukan unsur-unsur kerucut. Gambar 2 menunjukkan gambaran aktivittas siswa saat mengamati video konteks tradisi Megono Gunungan.

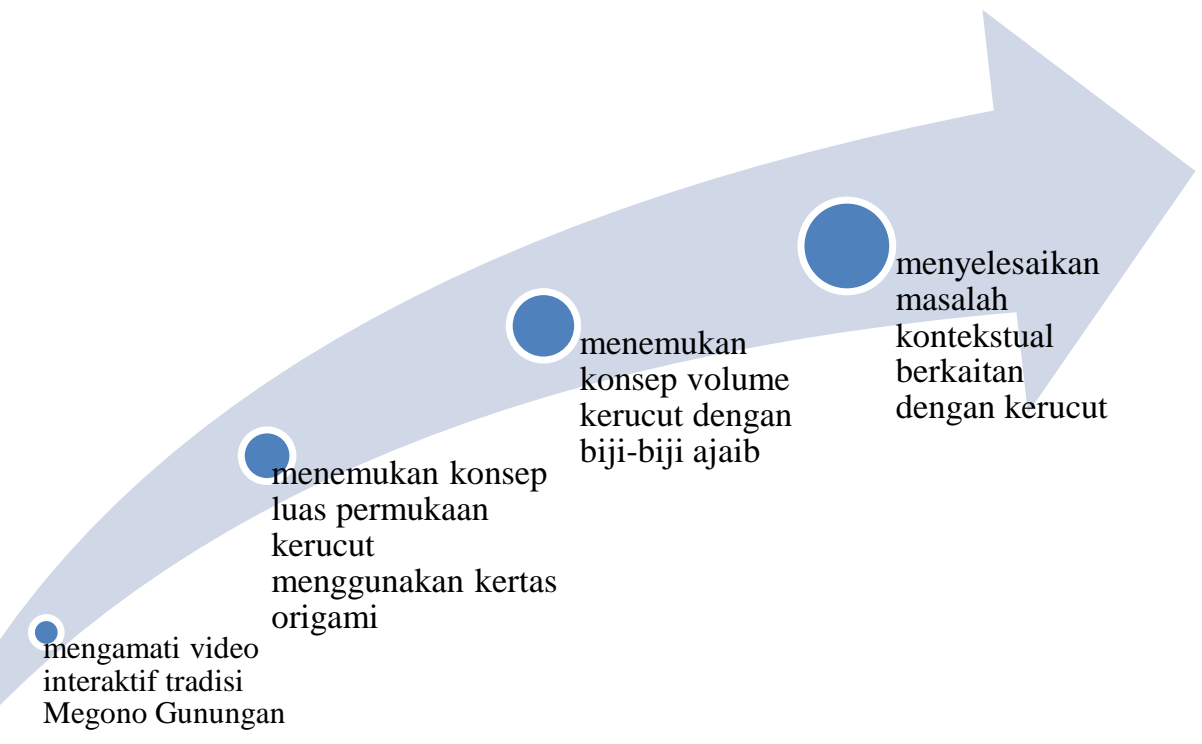

Gambar 1. Lintasan aktivitas pembelajaran kerucut

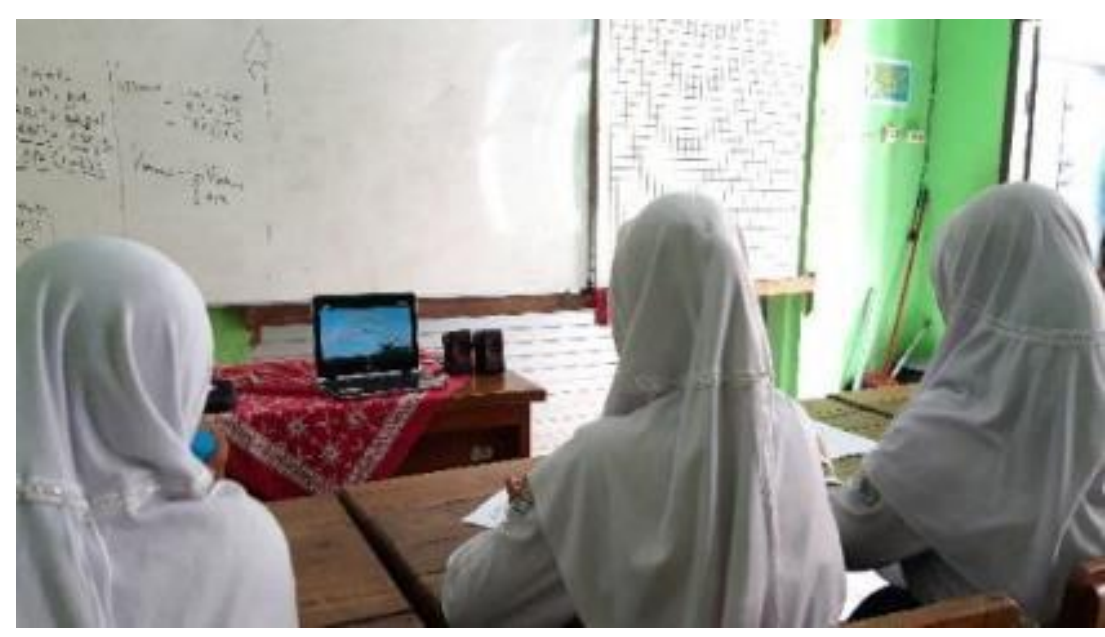

Gambar 2. Siswa mengamati video konteks Megono Gunungan dengan antusias

Kemudian, siswa diminta untuk berkelompok secara berpasangan untuk menyelesaikan masalah yang diberikan pada LAS 1. Dengan menggunakan konteks Megono Gunungan siswa dapat dengan mudah untuk mensketsakan bentuk Megono Gunungan yang berbentuk kerucut, mengidentifikasi, dan menentukan apa saja unsur-unsur yang terdapat pada kerucut. Siswa aktif dalam berdiskusi dalam menyelesaikan LAS 1. Setelah siswa menyelesaikan LAS 1, guru 
meminta salah satu kelompok untuk mengemukakan hasil diskusinya. Guru memperkenankan siswa lainnya jika ada hasil jawaban yang berlainan atau masih belum dipahami dan memberikan penguatan terhadap jawaban siswa. Gambar 3 menunjukkan hasil jawaban siswa pada aktivitas 1 .

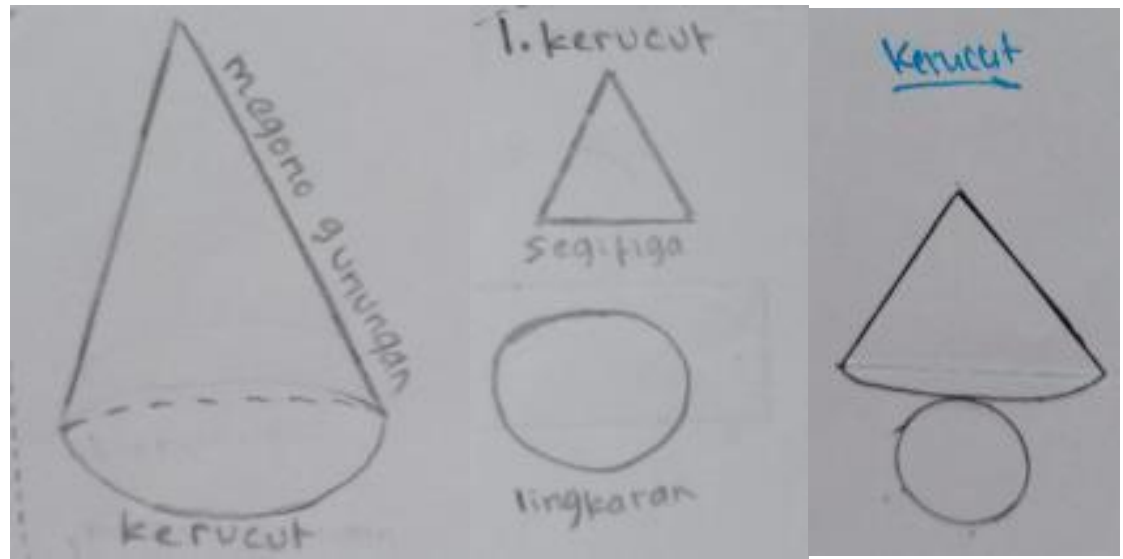

Gambar 3. Hasil jawaban siswa pada LAS 1

Pada gambar 3 dapat dilihat bahwa siswa dapat mengilustrasikan bentuk Megono Gunungan sebagai bentuk kerucut dengan benar dan dapat menentukan usur-unsurnya dengan tepat meski sebelumnya siswa menuliskan bagian juring kerucut sebagai bentuk segitiga. Setelah melakukan eksplorasi terhadap jawaban siswa melalui wawancara, peneliti dapat mengetahui pola pikir dari jawaban siswa dengan lebih mendalam. Berdasarkan hasil wawancara, siswa dapat menjelaskan jawabannya dengan jelas dan benar, bahwa bagian selimut kerucut bukan berbentuk segitiga tetapi juring yang hampir menyerupai segitiga. Selanjutnya, dapat disimpulkan bahwa siswa sudah dapat memahami konsep kerucut dan unsurunsurnya dengan tepat sesuai dengan tujuan pada aktivitas pertama.

\section{Aktivitas 2: Menemukan konsep luas permukaan kerucut menggunakan kertas origami}

Pada aktivitas 2 ini siswa diberikan LAS 2 dan kertas origami untuk menemukan konsep luas permukaan kerucut. Siswa diminta untuk dapat membentuk kerucut dari kertas origami yang diberikan dan kemudian menentukan jaring-jaringnya. Dalam proses membentuk kerucut siswa sangat bersemangat untuk bisa membentuk kerucut dari kertas origami. Hal tersebut dapat dilihat saat siswa terus mencoba berulang-ulang untuk bisa mendapatkan bentuk kerucut dengan sempurna. Gambar 4 menunjukkan gambaran kegiatan siswa pada aktivitas kedua. 


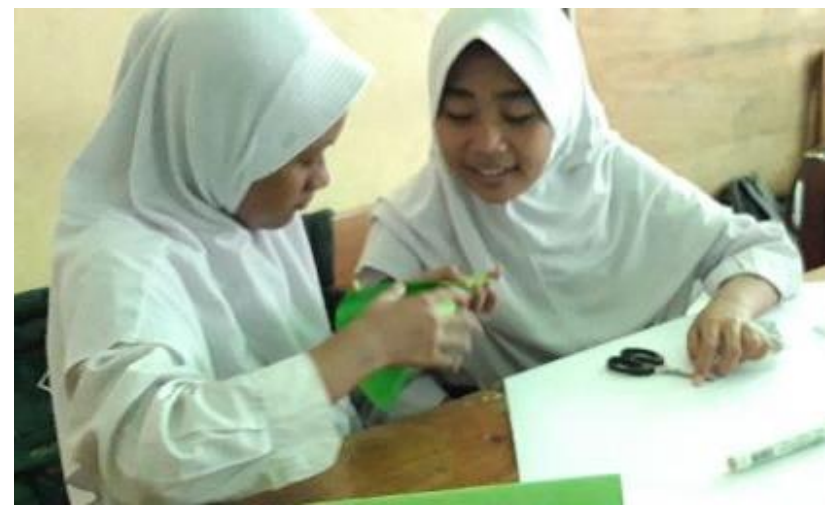

Gambar 4. Aktivitas siswa menemukan luas permukaan kerucut dengan kertas origami

Berdasarkan gambar 4 terlihat bahwa siswa begitu antusias dalam menyelesaikan masalah pada aktivitas 2 dengan bantuan kertas origami. Selain itu, dari hasil jawaban siswa pada LAS 2, siswa dapat menemukan konsep luas permukaan kerucut dengan benar dengan bantuan jaring-jaring dari kertas origami yang telah dibuat sebelumnya. Gambar 5 menunjukkan jawaban siswa pada aktivitas 2 .

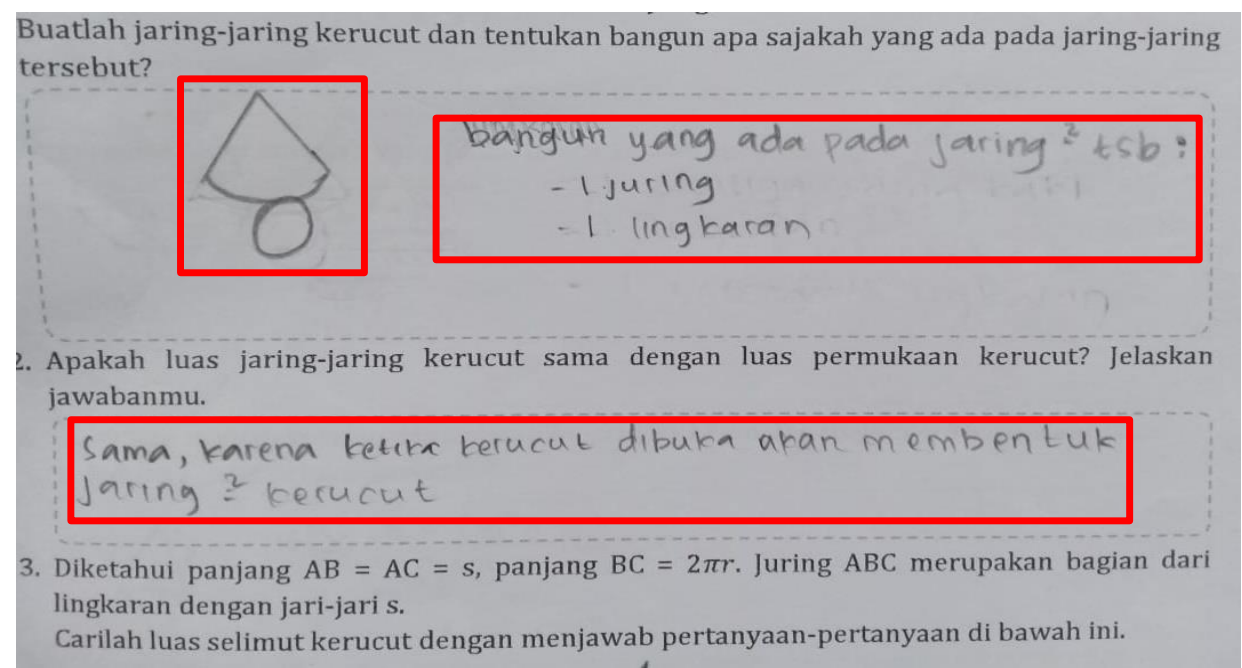

Gambar 5. Hasil jawaban siswa pada LAS 2

Berdasarkan gambar 5 dapat diketahui bahwa siswa mampu menggambarkan jaringjaring kerucut dan mengidentifikasi bagian-bagiannya. Selain itu siswa juga dapat menuliskan bahwa luas permukaan kerucut sama dengan luas jaring-jaring kerucut.

Selanjutnya, gambar 6 menunjukkan aktivitas siswa dalam menemukan rumus luas permukaan kerucut. Pada gambar 6 dapat diketahui bahwa siswa mampu menemukan rumus luas permukaan kerucut melalui serangkaian aktivitas di dalam LAS. Yaitu dengan menemukan luas selimut kerucut dengan mencari hubungan antara perbandingan luas juring dengan luas lingkaran dan perbandingan panjang busur dengan keliling lingkaran. Selanjutnya dapat diperoleh rumus luas permukaan kerucut yang merupakan gabungan antara luas selimut dan luas lingkaran penyusun kerucut tersebut. 


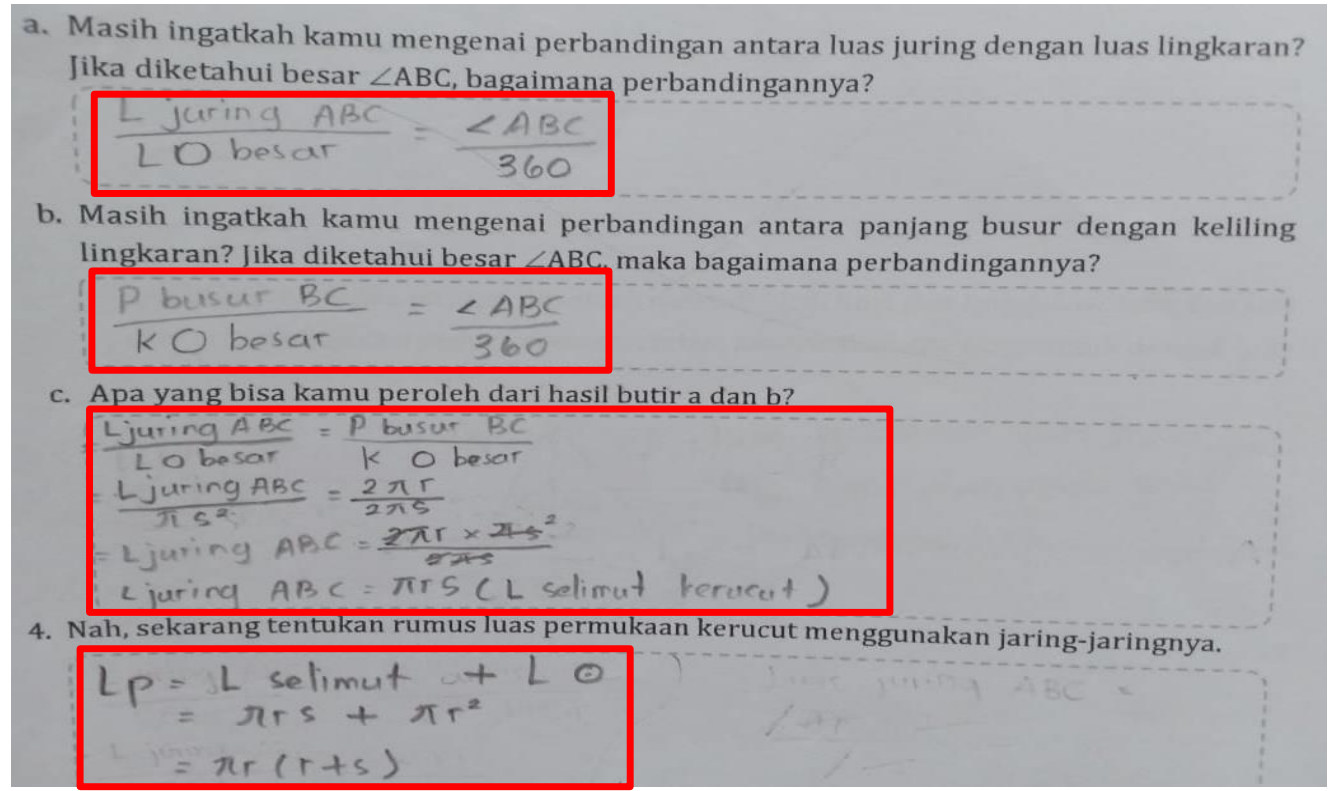

Gambar 6. Hasil jawaban siswa menemukan luas permukaan kerucut

\section{Aktivitas 3: Menemukan konsep volume kerucut dengan biji-biji ajaib}

Pada aktivitas 3, guru membagikan LAS 3 yang selanjutnya didiskusikan bersama kelompok masing-masing. Siswa melakukan eksperimen sederhana untuk menemukan konsep volume kerucut menggunakan biji-biji ajaib (kacang hijau, mutiara, beras merah) serta tabung dan kerucut tanpa alas yang memiliki tinggi dan diameter yang sama. Kemudian siswa diminta untuk mengisi kerucut sampai penuh dengan biji-biji ajaib yang pertama yaitu kacang hijau dan menuangkannya ke dalam tabung. Setelah itu siswa mengulangi kegiatan yang sama dengan biji-biji ajaib yang lain sampai tabung terisi penuh dengan biji-biji ajaib. Lalu, siswa diminta menentukan hubungan antara volume kerucut dan volume tabung, sehingga siswa dapat menemukan bahwa volume kerucut sama dengan sepertiga volume tabung. Pada aktivitas ini siswa diminta untuk dapat berpikir kritis dan menjadi pemecah masalah yang baik dari masalah yang diberikan. Gambar 7 menunjukkan aktivitas siswa pada saat eksperimen menggunakan biji-biji ajaib.

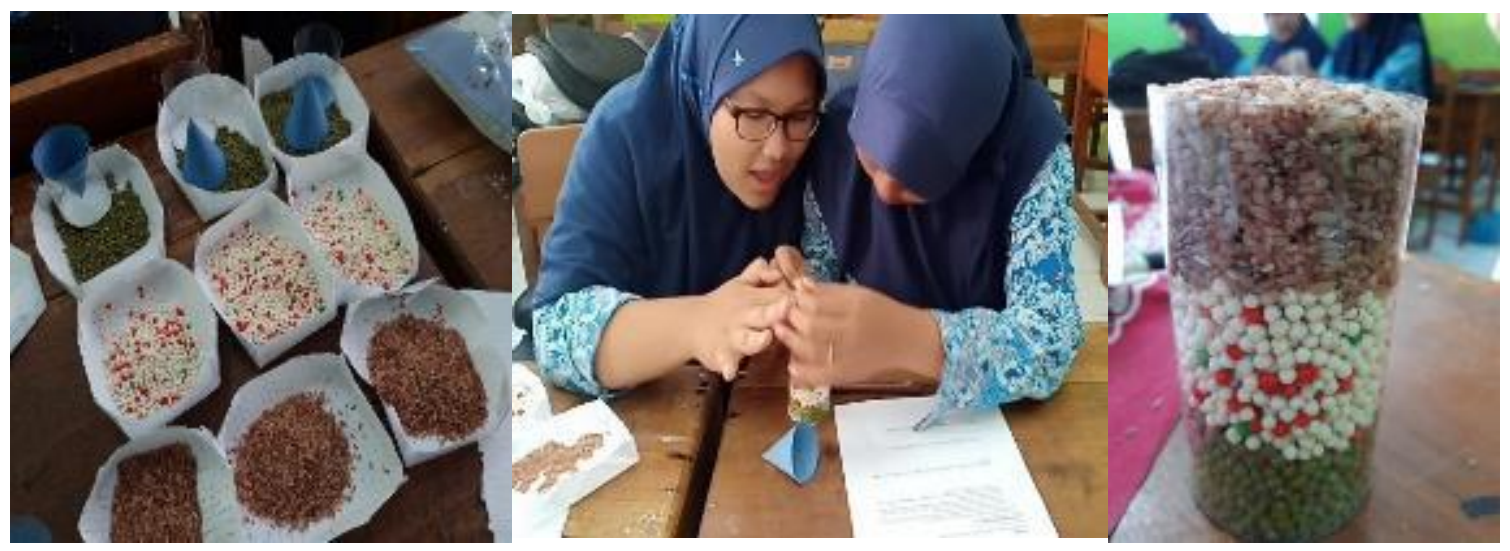

Gambar 7. Antusias siswa bereksperimen menemukan konsep volume kerucut 
Selain itu, berdasarkan jawaban siswa pada LAS 3, siswa mampu menemukan rumus volume kerucut melalui eksperimen yang telah dilakukan bersama kelompoknya dan menuliskannya pada LAS. Gambar 8 menunjukkan hasil jawaban siswa pada LAS 3.

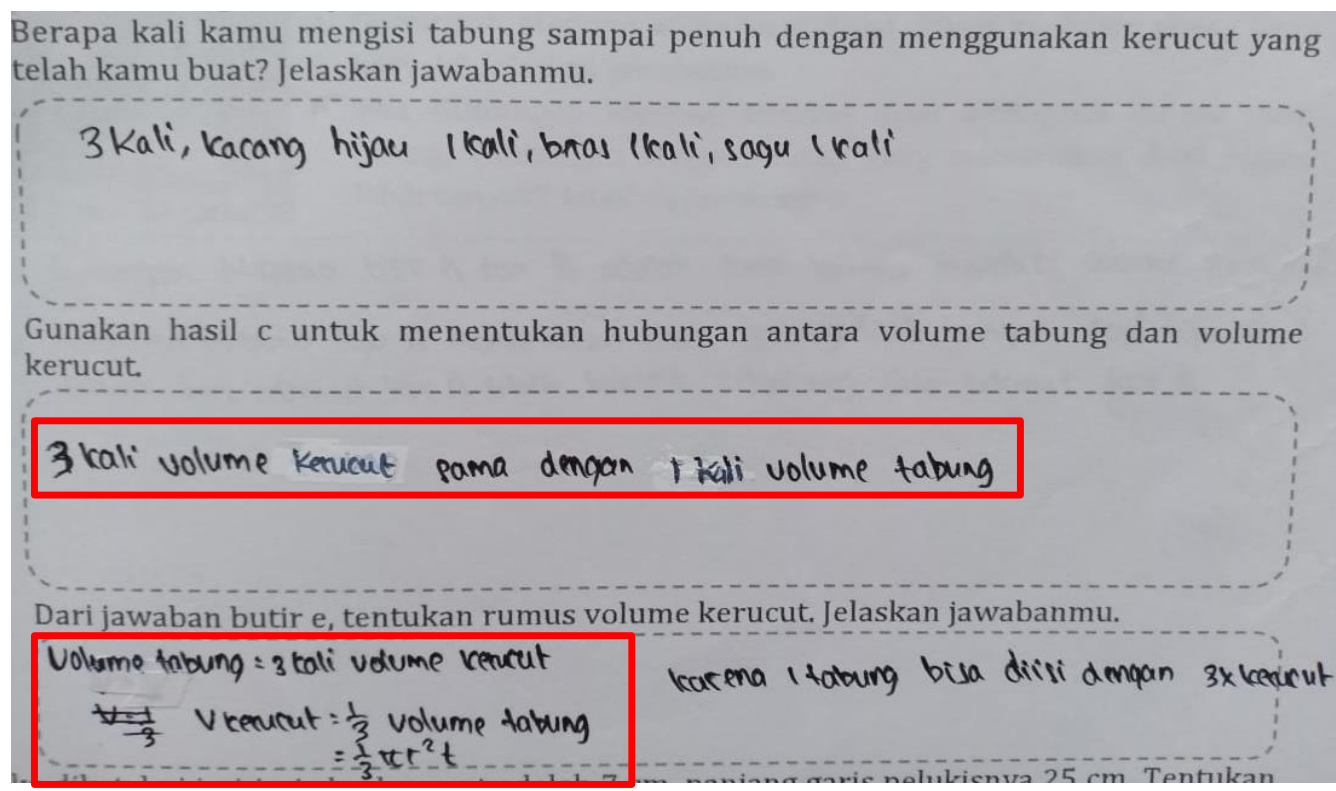

Gambar 8. Jawaban siswa pada aktivitas 3

Selanjutnya, cuplikan wawancara dengan siswa pada aktivitas ini dapat ditunjukkan sebagai berikut.

Peneliti : "bagaimana eksperimennya tadi?"

Siswa : "menyenangkan Bu"

Peneliti : "untuk mengisi tabung dengan biji-biji ajaib ini sampai penuh tadi bagaimana?"

Siswa : "tadi kami mengisinya menggunakan kerucut ini Bu, kami mengisi kerucut ini dengan biji kacang hijau sampai penuh lalu dituangkan ke tabung, terus beras 1 kali, dan sagu 1 kali, kemudian tabung ini jadi penuh seperti ini"

Peneliti : "ada berapa kali tadi mengisi biji-bijian ini menggunakan kerucut sehingga isi tabungnya menjadi penuh?"

Siswa : "kacang hijau 1 kali, beras 1 kali, dan sagu 1 kali Bu"

Peneliti : "jadi ada berapa kali mengisi kerucut untuk bisa mengisi tabung sampai penuh?"

Siswa : "3 kali Bu"

Peneliti : "Bagus, apa yang bisa diperoleh dari eksperimen tadi?"

Siswa : "3 kali volume kerucut sama dengan 1 kali volume tabung"

Dari wawancara tersebut dapat disimpulkan bahwa siswa mampu menemukan hubungan volume tabung dengan volume kerucut dan mendefinisikan volume kerucut melalui eksperimen yang telah dilakukan sebelumnya, yaitu volume tabung adalah tiga kali volume kerucut sehingga volume kerucut adalah $\frac{1}{3}$ dari volume tabung. Hasil tertulis dan wawancara menunjukkan bahwa tujuan pada aktivitas 3 ini telah tercapai. 


\section{Aktivitas 4: Menyelesaikan masalah kontekstual berkaitan dengan kerucut}

Pada aktivitas 4, siswa diminta untuk mengerjakan LAS 4 yang memuat masalah kontekstual berkaitan dengan kerucut. Siswa berdiskusi kelompok untuk dapat menyelesaikan masalah kontekstual yang diberikan. Selanjutnya, jawaban siswa pada aktivitas 4 dapat dilihat pada gambar 9.

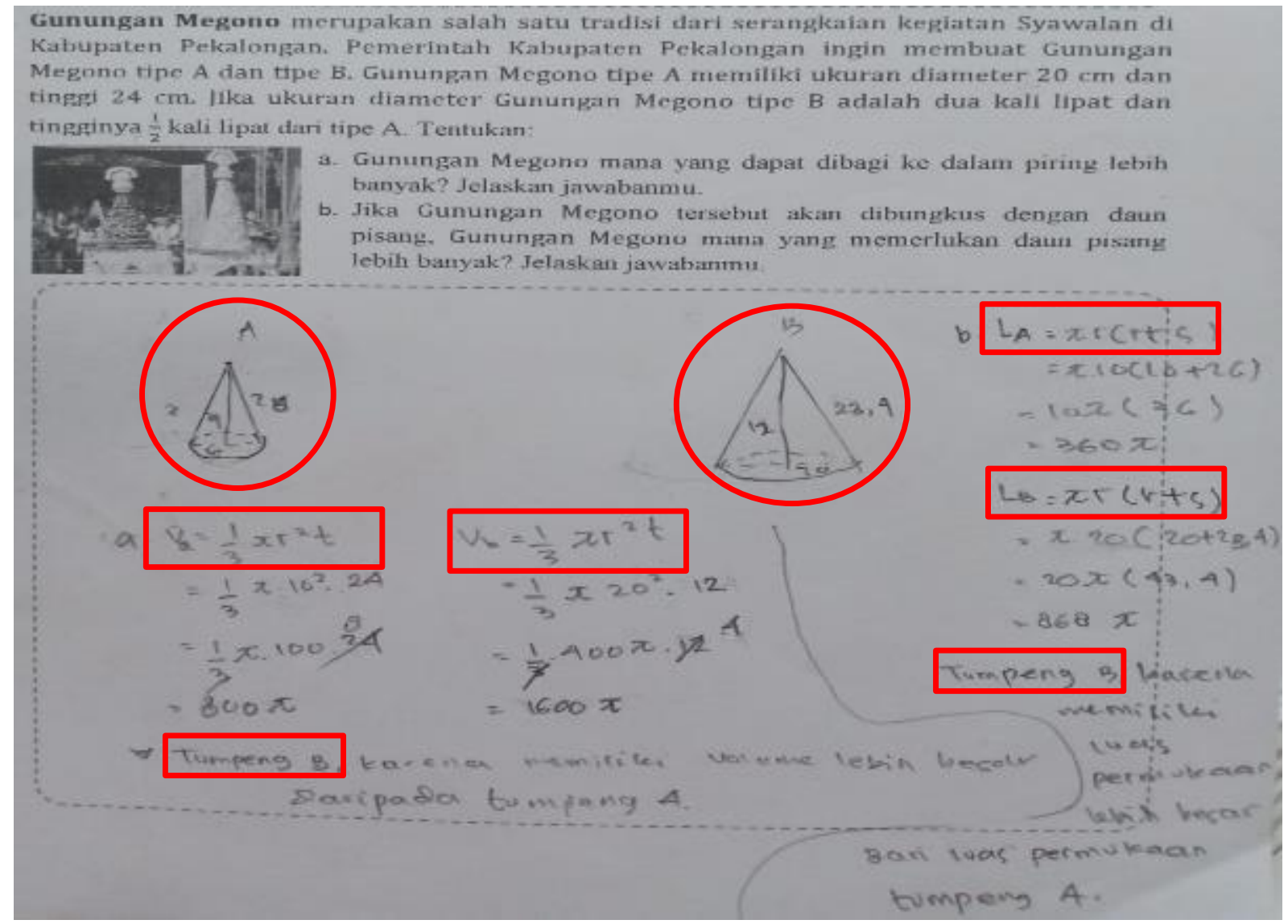

Gambar 9. Jawaban siswa pada aktivitas 4

Berdasarkan gambar 9, dapat diketahui bahwa siswa dapat mengaplikasikan konsep volume dan luas permukaan kerucut untuk menyelesaikan masalah kontekstual yang berkaitan dengan kerucut. Hal tersebut dapat ditunjukkan melalui kemampuan siswa dalam membuat ilustrasi gambar Megono Gunungan tipe A dan tipe B sebagai bentuk kerucut yang mempunyai ukuran berbeda. Selanjutnya, siswa mampu menuliskan dan mengaplikasikan rumus volume maupun luas permukaan kerucut untuk menyelesaikan masalah yang diberikan. Siswa dapat menentukan Megono Gunungan mana yang menghasilkan lebih banyak jika dibagi rata dan Megono Gunungan mana yang membutuhkan daun pisang lebih banyak. Dengan menggunakan prinsip yang telah dipelajari pada aktivitas sebelumnya, siswa mampu menyelesaikan masalah dengan baik dan benar. Hasil tersebut sesuai dengan tujuan dari lintasan pembelajaran yang dirancang. 


\section{Pembahasan}

Pemahaman siswa mengenai materi kerucut dapat didukung dengan rancangan lintasan pembelajaran menggunakan konteks Megono Gunungan yang dikemas dalam bentuk video interaktif. Pemahaman siswa dapat dikembangkan dari tahap informal ke formal sebagaimana ditunjukkan pada gambar 2 sampai dengan gambar 9. Selain itu, aktivitas pembelajaran yang dirancang juga dapat mengubah pandangan siswa bahwa matematika yang dirasa jauh dari kehidupan sehari-hari ada dan merupakan bagian dari tradisi masyarakat sejak lampau. Pendekatan PMRI dengan konteks kearifan lokal tradisi Megono Gunungan dapat digunakan sebagai titik awal pembelajaran kerucut. Hal tersebut karena konteks tradisi Megono Gunungan merupakan tradisi lokal yang dekat dengan siswa sehingga memudahkan siswa dalam menemukan konsep kerucut. Beberapa penelitian sebelumnya juga telah menggunakan konteks lokal dalam pembelajaran matematika, seperti kerajinan tangan Indonesia (anyaman) dalam pembelajaran pengukuran dan geometri (Haris \& Putri, 2011); permainan tradisional dalam pembelajaran perkalian, penjumlahan, dan aritmatika sosial (Prahmana, et al., 2012; Nursyahidah, et al., 2013; Risdayanti, et al., 2019); cerita wayang dan uno stucko dalam pembelajaran pola bilangan (Risdiyanti \& Prahmana, 2020); dan bangunan bersejarah dalam pembelajaran refleksi pada transformasi geometri (Nursyahidah, et al., 2020).

Selain itu, pembelajaran kerucut dengan konteks Megono Gunungan juga dapat meningkatkan minat dan motivasi siswa dalam proses pembelajaran. Dalam hal ini siswa aktif dalam diskusi kelompok dan kelas untuk dapat menyelesaikan masalah yang diberikan dengan bantuan eksperimen sederhana. Hal ini selaras dengan beberapa penelitian (Nasrullah \& Zulkardi, 2011; Bustang, et al., 2013; Juwita, dkk., 2015; Nursyahidah, dkk., 2013, 2014, 2018, 2020; Risdayanti, Prahmana, \& Shahrill, 2019; Risdiyanti \& Prahmana, 2020) yang menyatakan bahwa penggunaan pendekatan PMRI dalam kegiatan belajar mengajar dengan menggunakan konteks yang sesuai dapat memudahkan siswa menguasai konsep yang dipelajari serta meningkatkan minat dan motivasi siswa dalam proses pembelajaran matematika. Dengan bantuan konteks tradisi Megono Gunungan yang merupakan tradisi kearifan lokal Jawa Tengah yang akrab dengan siswa yang dikemas dalam sebuah video interaktif agar siswa lebih bersemangat dan aktif dalam proses pembelajaran sehingga dapat memahami konsep yang dipelajari secara mendalam dan menjadikan pembelajaran lebih bermakna.

\section{Simpulan}

Lintasan pembelajaran yang dihasilkan dalam penelitian ini terdiri dari empat aktivitas, yaitu mengamati video interaktif tradisi Megono Gunungan untuk menemukan unsur-unsur 
kerucut, menemukan konsep luas permukaan kerucut menggunakan kertas origami, menemukan konsep volume kerucut dengan biji-biji ajaib, dan menyelesaikan masalah kontekstual berkaitan dengan kerucut. Hasil penelitian ini menunjukkan bahwa melalui serangkaian aktivitas yang telah dirancang dapat membantu menstimulasi pemahaman konsep luas permukaan dan volume kerucut dengan menggunakan konteks tradisi Megono Gunungan yang dikemas dalam bentuk video interaktif yang menyenangkan.

\section{Referensi}

Adelabu, F. M., Makgato, M., and Ramaligela, M. S. (2019). The importance of Dynamic Geometry Computer Software on learners' performance in geometry. The Electronic Journal of E-Learning, 17(1), 52-63. Diambil dari https://files.eric.ed.gov/fulltext/EJ1216699.pdf.

Alex, J. K., \& Mammen, K. J. (2012). A survey of South African grade 10 learners' geometric thinking levels in terms of the Van Hiele theory. Anthropologist, 14(2), 123-129. https://doi.org/10.1080/09720073.2012.11891229.

Anderson, T., \& Shattuck, J. (2012). Design-based research. Educational Researcher, 41(1), 16-25. https://doi.org/10.3102/0013189X11428813.

Arifin, Yusmin, E., \& Hamdani. (2018). Analisis kesulitan belajar siswa pada materi bangun ruang sisi lengkung di SMP. Jurnal Pendidikan dan Pembelajaran Khatulistiwa, 6(4), 113.

Armah, R. B., Cofie, P. O., \& Okpoti, C. A. (2018). Investigating the effect of van Hiele Phasebased instruction on pre-service teachers' geometric thinking. International Journal of Research in Education and Science (IJRES), 4(1), 314-330. https://doi.org/10.21890/ijres.383201.

Bakker, A. (2004). Design research in statistics education-on symbolizing and computer tools. Utrecht: CD Beta Press.

Bhagat, K. K., \& Chang, C. (2015). Incorporating GeoGebra into geometry learning:A lesson from India. Eurasia Journal of Mathematics, Science \& Technology Education, 11(1), 77-86. https://doi.org/10.12973/eurasia.2015.1307a.

Bustang, Zulkardi, Darmowijoyo, Dolk, M. \& Van Eerde, D. (2013). Developing a local instruction theory for learning the concept of angle through visual field activites and spatial representation. International Education Studies. 6(8). 58-70 https://doi.org/10.5539/ies.v6n8p58.

Clements, D. H., \& Sarama, J. (2011). Early childhood teacher education: The case of geometry. Journal of Mathematics Teacher Education, 14(2), 133-148. https://doi.org/10.1007/s10857-011-9173-0.

Couto, A., \& Vale, I. (2014). Pre-service teachers' knowledge on elementary geometry concepts. Journal of the European Teacher Education Network, 9, 57-73. Diambil dari http://jeten-online.org/index.php/jeten/article/view/32/57-73.

Doğruer, S. S. (2018). Developing eighth grade students' mathematical practices in solids through argumentation: A design-based study. Disertasi tidak dipublikasikan, Ankara, Middle East Technical University. Diambil dari http://etd.lib.metu.edu.tr/upload/12622252/index.pdf.

Gravemeijer, K., \& Cobb, P. (2006). Design research from a learning design perspective. Dalam (Eds) van den Akker, J., Gravemeijer, K., McKenney, S., \& Nieveen, N., Educational design research (h.17-51). New York: Routledge. 
https://doi.org/10.4324/9780203088364.

Haris, D., \& Putri, R.I.I. (2011). The role of context in third graders' learning of area measurement. Journal on Mathematics Education, 2(1), 55-66. https://10.22342/jme.2.1.778.55-66.

Juwita, H., Putri, R. I. I., \& Somakim. (2015). Peranan buah semangka dalam pembelajaran volume bola. Jurnal Elemen, 1(2), 130-143. https://doi.org/10.29408/jel.v1i2.145.

Kemendikbud. (2016). Lampiran Permendikbud Nomor 24 Tahun 2016 Tentang Standar Kompetensi Isi dan Kompetensi Dasar Pendidikan Dasar dan Menengah. Jakarta: Kemendikbud.

Keşan, C., \& Çalışkan, S. (2013). The effect of learning geometry topics of 7th grade in primary education with dynamic Geometer's Sketchpad geometry software to success and retention. TOJET: The Turkish Online Journal of Educational Technology, 12(1), 131138. Diambil dari https://files.eric.ed.gov/fulltext/EJ1008875.pdf.

Lithner, J. (2011). University Mathematics Students' Learning Difficulties. Education Inquiry, 2(2) 289 - 303. https://doi.org/10.3402/edui.v2i2.21981.

Mostafa, M., Javad, M. L., \& Reza, O. (2016). The effect of Van Hiele Theory-Based teaching educational package on achievement goal orientation of student teachers. Review of European Studies, 9(1), 93-105. https://doi.org/10.5539/res.v9n1p93.

Najafipour, M., \& Jafari, E. M. (2013). The effect of the active teaching method on the academic achievement in the religious concepts. Procedia-Social and Behavioral Sciences, 83, 204-207. https://doi.org/10.1016/j.sbspro.2013.06.040.

Nasrullah \& Zulkardi. (2011). Building counting by traditional game a mathematics program for young children. Journal on Mathematics Education, 2(1), 41-54. https://doi.org/10.22342/jme.2.1.781.41-54.

National Council of Teachers of Mathematics [NCTM]. (2000). Principles and standards for school mathematics. Reston, VA: NCTM.

Novita, R., Prahmana, R. C. I., Fajri, N., \& Putra, M. (2018). Penyebab kesulitan belajar geometri dimensi tiga. Jurnal Riset Pendidikan Matematika, 5(1), 18-29. https://doi.org/10.21831/jrpm.v5i1.16836.

Nursyahidah, F., Putri, R. I. I., \& Somakim. (2013). Supporting first grade student's understanding of addition up to 20 using traditional game. IndoMS-JME, 4(2), 212-223. https://doi.org/10.22342/jme.4.2.557.212-223.

Nursyahidah, F., Putri, R. I. I., \& Somakim. (2014). Instructional design of subtraction using PMRI approach based on traditional game. Proceeding of the 2nd SEA-DR. Palembang: Universitas Sriwijaya. Diambil dari https://repository.unsri.ac.id/6836/.

Nursyahidah, F., Saputro, B. A., \& Rubowo, M. R. (2018). A secondary student's problem solving ability in learning based on realistic mathematics with ethnomathematics. Journal of Research and Advances in Mathematics Education, 3(1), 13-24. https://doi.org/10.23917/jramathedu.v3i1.5607.

Nursyahidah, F., Saputro, B. A., Albab, I., \& Aisyah, F. (2020). Pengembangan learning trajectory-based instruction materi kerucut menggunakan konteks Megono Gunungan. Mosharafa: Jurnal Pendidikan Matematika, 9(1), 47-58. https://journal.institutpendidikan.ac.id/index.php/mosharafa/article/view/mv9n1_05.

Nursyahidah, F., Saputro, B. A., \& Albab, I. (2020). Learning reflection through the context of Central Java historical building. Journal of Physics: Conference Series, 1567 022095. 1-6. https://doi.org/10.1088/1742-6596/1567/2/022095.

Özdemir, B. G. (2017). Mathematical practices in a learning environment designed by Realistic Mathematics Education: Teaching experiment about cone and pyramid. European Jornal of Education Studies, 3(5), 405-430.

Prahmana, R. C. I., Zulkardi, \& Hartono, Y. (2012). Learning multiplication using indonesian 
traditional game in third grade. Journal on Mathematics Education, 3(2), 115-132. https://doi.org/10.22342/jme.3.2.1931.115-132.

Prahmana, R. C. I. (2017). Design research (teori dan implementasinya: suatu pengantar). Jakarta: Rajawali Pers.

Putri, R. I. I., \& Zulkardi. (2019). Designing jumping task on percent using PMRI and collaborative learning. International Journal on Emerging Mathematics Education (IJEME), 3(1), 105-115. https://doi.org/10.12928/ijeme.v3i1.12208.

Putri, R. I. I., \& Zulkardi. (2017). Fraction in shot-put: A learning trajectory. AIP Conference Proceedings, (1)1868, 050005. https://doi.org/10.1063/1.4995132.

Risdiyanti, I., Prahmana, R. C. I., \& Shahrill, M. (2019). The learning trajectory of social arithmetic using an Indonesian traditional game. Elementary Education Online, 18(4), 2094-2108. https://doi.org/10.17051/ilkonline.2019.639439.

Risdiyanti, I., \& Prahmana, R.C.I. (2020). The learning trajectory of number pattern learning using Barathayudha war stories and Uno Stacko. Journal on Mathematics Education, 11(1), 157-166. https://doi.org/10.22342/jme.11.1.10225.157-166.

Serin, H. (2018). Perspectives on the teaching of geometry: Teaching and learning methods. Journal of Education and Training, 5(1), 1-7 https://doi.org/10.5296/jet.v5i1.12115.

Sinclair, N., \& Bruce, C. (2015). New opportunities in geometry education at the primary school. ZDM Mathematics Education, 47(3), 319-329. https://doi.org/10.1007/s11858015-0693-4.

Yanti, W., Hartono, Y., \& Somakim. (2016). Desain pembelajaran peluang dengan pendekatan PMRI menggunakan kupon undian untuk siswa kelas VII. Jurnal Elemen, 2(1), 56-71. https://doi.org/10.29408/jel.v2i1.177.

Yavuz, A., Aydin, B. \& Avci, M. (2016). The effect of the success in teaching geometry of basic level education mathematics. European Journal of Education Studies, 2(8), 59-71. 